\title{
Crisis' consequences on recapitalization and exposure for Cypriot and Greek cooperative banks
}

\author{
Simeon Karafolas \\ Akis Kleanthous
}

ABSTRACT: The financial crisis of 2008 transformed, in some countries, to economic and social one, created serious problems to the banking system. Capital basis and asset exposures, especially through the non-performing loans, have been the most important. Capital inadequacy caused the failure of banks that didn't succeed to accomplish the capital requirements set by Basel II obligations.

The treatment was not the same for all banks as only those considered as significant banks, for the economy, received capital aid from their state. The paper investigates through capital basis requirements and asset exposures the crisis' consequences on Cyprus and Greek cooperative banks. The consequences were cataclysmic for the cooperative banking systems of the two countries. In Greece, the cooperative banks did not receive any state aid, leading to the bankruptcy of many of them. In Cyprus, once all the cooperative banks were merged into the central cooperative bank, the latter received state aid as it was considered as a significant bank for the national economy. Moreover, the high level of non-performing loans and the new economic environment that the crisis had caused, forced the cooperative banks to change their asset exposures structure and their credit policy.

KEY WORDS: Cooperative banks, credit risk, recapitalization, crisis, Cyprus, Greece.

ECONLIT CODES: E44, G01, G21, G32, G33.

How to cite this article: KARAFOLAS, S. \& KLEANTHOUS, A. (2019): "Crisis' consequences on recapitalization and exposure for Cypriot and Greek cooperative banks", CIRIEC-España, Revista de Economía Pública, Social y Cooperativa, 96, 5-27. DOI: 10.7203/CIRIEC-E.96.12974.

Correspondence: Contact e-mail: karafola@teiwm.gr. 


\section{RESUMEN AMPLIO}

\section{Las consecuencias de las crisis en la recapitalización y las exposiciones de los activos para los bancos cooperativos chipriotas y griegos}

\section{Objetivos y Diseño de la investigación}

La crisis financiera, que en algunos países se transformó en económica y social, creó serios problemas en el sistema bancario. Los casos de Grecia y de Chipre son unos de los ejemplos más típicos. La base de capital y las exposiciones de los activos, especialmente a través de los préstamos no rentables, han sido los problemas más importantes. La inadecuación de capital causó el fracaso de los bancos, que no lograron cumplir con los requisitos de capital establecidos por las obligaciones de Basilea II. El trato no fue el mismo para todos los bancos puesto que algunos recibieron ayuda financiera del Estado mientras que otros no pudieron recibirla. Los primeros son los considerados "significativos" para la economía y los segundos se consideran bancos "no significativos".

El objetivo de este artículo es examinar las consecuencias de la crisis en los bancos cooperativos de Chipre y de Grecia a través de los requerimientos de las bases de capital y las exposiciones de los activos.

El análisis de las consecuencias de la crisis se basa en dos puntos metodológicos. Por una parte, se investiga las consecuencias de la inadecuación de capital en la evolución del sistema bancario cooperativo en los dos países. Por otra parte, se analiza el comportamiento de los bancos cooperativos durante la crisis a través de las exposiciones de los activos. En el primer caso, se examinan las consecuencias catalíticas de la incapacidad de encontrar capitales y de la ausencia de ayuda pública a los bancos cooperativos griegos. Al mismo tiempo, se analizan las acciones realizadas en ambos los países para afrontar las consecuencias. En el segundo caso, el comportamiento de los bancos en Grecia y Chipre se estudia a través de la evolución de las exposiciones tanto en tamaño como en estructura. El análisis se realiza en base a los tipos de exposiciones de los activos. Estos tipos (segmentos regulatorios) son: Administraciones centrales o bancos centrales, Administraciones regionales 0 autoridades locales, Bancos, Exposiciones garantizadas por hipotecas sobre bienes inmuebles, Exposiciones minoristas, Empresas, Exposiciones en situación de default, Otras partidas.

El período investigado es del 2010 hasta el 2016, el cual es un período crítico de la crisis financiera en ambos países. Grecia en el 2010 y Chipre en el 2012 firmaron el Memorándum de Entendimiento con sus acreedores coadyuvaron a una recesión económica en estos países. En el 
caso de Grecia se analizan tres bancos cooperativos en tres regiones diferentes; Creta (Banco Cooperativo de Chania), Epiro (Banco Cooperativo de Epiro) y Macedonia Oriental y Tracia (Banco Cooperativo de Ebro). El examen se realiza en base consolidada. En el caso de Chipre se examina el Banco Cooperativo Central de Chipre.

El objetivo es examinar el comportamiento de los bancos cooperativos griegos en comparación con el Banco Cooperativo Central de Chipre. Las preguntas de investigación planteadas son: ¿los bancos cooperativos en Grecia y en Chipre siguieron una política más conservadora o una política de alto riesgo en relación con los préstamos durante la crisis? Y durante este período, ¿han cambiado o no esas políticas? Estas preguntas se pueden contestar examinando las exposiciones de los activos ya que cada tipo de exposición está caracterizada por una ponderación de riesgo específica. Aquellas ponderaciones se cifran en $0 \%$ para los activos sin riesgo, 20\% para los activos de bajo riesgo, 35\% y $50 \%$ para los activos normalmente garantizados por una hipoteca, $75 \%$ y $100 \%$ para los activos principalmente relacionados con préstamos de consumo y de negocios, finalmente más de $150 \%$ relacionados con préstamos en atraso. Estos datos proceden de los informes anuales de los cuatro bancos sobre la adecuación de capital y la gestión del riesgo según el Pilar 3.

\section{Resultados}

Los resultados de la investigación en el primer punto en relación con el desarrollo del sistema bancario cooperativo revelan las evoluciones catalíticas en los dos países. Por un lado, en Grecia siete de los dieciséis bancos cooperativos se declararon en quiebra ya que no lograron cubrir las necesidades de capital. Aún así, estos bancos no fueron financiados por el Estado como pasó con los cuatro grandes bancos griegos, los cuales son considerados como claves para la economía. Por otro lado, en Chipre se produjo un enorme movimiento de concentración en los bancos cooperativos dado que en 2010 los 347 bancos cooperativos disminuyeron hasta 111, y en 2014, después de las fusiones quedaron sólo 19. Al final, en 2017 todas las entidades cooperativas de crédito se fusionaron en un solo banco, el Banco Cooperativo Central de Chipre, que logró ser considerado importante para la economía y recibió financiación pública para su recapitalización.

Los resultados de la investigación en el segundo punto con respecto a la evolución y la estructura de las exposiciones de los activos muestran que las consecuencias de la crisis fueron catalíticas. Tanto en Grecia como en Chipre, la categoría relacionada con las aperturas en retraso es la más grande en el período bajo investigación con un aumento progresivo. Estas aperturas constituyen una media de un 24,1\% del total durante el período 2010-2016 en el caso de Grecia y el 25\% en el caso de Chipre. Sin embargo, el caso de Chipre se diferencia del de Grecia en el tipo de exposiciones sin riesgo, ya que una gran parte de ellas concierne a los gobiernos centrales y los bancos centrales comprando bonos del Estado. La media del período es de un 22\% para el Banco Cooperativo Central de Chipre mientras que para los bancos griegos es sólo de un 2,6\%. Al contrario, durante el mismo período en 
Grecia los préstamos de negocios predominan con un 15,2\% mientras en Chipre constituyen un 2\%. Los dos tipos que quedan, es decir, los préstamos hipotecarios residenciales y de consumo, representan un tercio del total en ambos casos según el año examinado.

Durante este período se observa en ambos casos un aumento de la importancia de las aperturas en retraso. Además, se aprecia una políica más conservadora en los dos países. En el caso griego, las aperturas garantizadas por una hipoteca se incrementan en las de riesgo cero, como los bonos del Estado. En el caso de Chipre, aumentan particularmente las aperturas con riesgo cero, es decir, los bonos del Estado.

\section{Limitaciones de la investigación}

Examinando las exposiciones de los activos, el trabajo se centra en tres bancos cooperativos de Grecia. Esto es debido a que estos bancos prestan todos los datos necesarios en relación con el resto de los bancos. Aunque los bancos examinados puedan ser considerados representativos del conjunto total, no se puede negar que existe una limitación en los resultados. Con respecto al caso de los bancos de Chipre, los resultados se refieren al total, dado que el Banco Cooperativo Central de Chipre los incluye a todos. Otra limitación se debe al hecho de que los datos están analizados en base al tipo de aperturas y en base al porcentaje de riesgo (Karafolas, 2017). Esto resulta en una diferenciación de la ponderación de riesgo dentro de un tipo, si se considera que algunos datos no conllevan riesgo, y al revés.

\section{Conclusiones prácticas y originalidad}

Como ya fue estudiado en otra investigación (Karafolas, 2016), existen diferencias entre los sistemas cooperativos. La crisis financiera tuvo consecuencias graves para la recapitalización de los bancos y en algunos casos catalizadoras para el sistema bancario cooperativo en sí. Este trabajo demuestra la existencia de este problema y es uno de los pocos -quizás el único- que investiga el problema de forma comparativa. Además, se puede considerar un ejemplo de un estudio más general de las consecuencias de la crisis en el sistema de crédito cooperativo. Este último, en muchos casos no logró tener en cuenta los compromisos exigidos en el marco de Basilea II sobre las necesidades de capital de las entidades de crédito y la gestión de riesgo. Los cambios catalíticos en los sistemas bancarios cooperativos de Chipre y de Grecia deben ser el ejemplo de un debate general sobre las entidades de crédito cooperativas, especialmente dentro de los países donde este fenómeno es nuevo, como por ejemplo los países de la Europa del Este, pero también en países donde su funcionamiento no tuvo en cuenta los compromisos de capital, por ejemplo Inglaterra.

PALABRAS CLAVE: Bancos cooperativos, riesgo de crédito, recapitalización, crisis, Chipre, Grecia. 


\section{Introduction}

Credit risk is the main risk a bank is subject to; other risks include concentration risk, country risk, market risk, interest rate risk, foreign exchange risk, operational risk, settlement risk and, leverage risk. Credit risk is defined as the potential risk that a bank's borrower or counterparty will fail to meet obligations in accordance with agreed terms and conditions. Bank's exposure values are classified into categories on the basis of the borrower or the kind of credit. On every credit a risk weight is applied depending on the risk of the exposure value. The exposure value multiplied by risk weight determines the total risk exposure amount. This amount determines the regulatory capital a bank needs since the total capital ratio of a bank is defined as the ratio of regulatory capital over the total risk exposure amount.

In 1988, the Basel Committee, at the Bank of International Settlements, developed the framework regarding the capital adequacy of banks. The ratio between the capital and weighted assets of a bank had to be $8 \%$. A lower ratio would demand an increase in the capital of the bank. The European Union laid down additional rules regarding the market risk for the banks. The need for better knowledge of risks undertaken by banks reinforced the creation of a new regulatory framework known as Basel II. It is divided into 3 pillars as follows (Basel Committee 2006):

- Pillar I defines the minimum regulatory capital requirement based on principles and rules that specify and measure credit, market and operational risk.

- $\quad$ Pillar II designs the process for estimating the total capital adequacy related to all risks the bank can take through the Internal Capital Adequacy Assessment Process (ICAAP).

- Pillar III determines the disclosure requirements that permit market participants to have a good knowledge of risks undertaken by banks and therefore the capital adequacy for banks, which depends on the weighted assets of the bank.

The application of Basel II requirements was enforced on Cyprus and Greece due to the financial and economic crisis.

The paper focuses on cooperative banks as a specific example. Cooperative banks, as all other banks, had to face the problems created by credit risk since banks' borrowers or counterparties failed to repay their loans. Capital inadequacy precipitated the failure of some Greek cooperative banks since they did not succeed in meeting the Basel II capital requirements and they did not receive financial support from the Financial Stability Fund (FSF). In contrast, the FSF offered the necessary capital to the significant banks (European Central Bank, 2017). In the Greek case they are Alpha Bank, Eurobank, National Bank of Greece and Piraeus Bank; in the Cypriot case the financing assistance for the recapitalization was accorded to the Cypriot Central Cooperative Bank. In the case of Greece, due to merg- 
ers and acquisitions in the decades of 2000 and 2010, the four above banks had covered more than $97 \%$ of the Greek banking market by the end of 2016 (European Central Bank, 2017a).

This paper examines the consequences of the regulation on capital adequacy for the Greek and Cypriot cooperative banks during the crisis period. The consequences have been very serious, not to say dramatic. In Greece, the failure to achieve the capital requirements led to the bankruptcy of several cooperative banks, which in turn caused a reduction in the aggregate figures of cooperative banks as expressed by total assets and the number of branches. The paper examines also the exposures of cooperative banks during the crisis through a comparative analysis based on the examples of three Greek cooperative banks and Cypriot Central Cooperative Bank. In the Greek case the three cooperative banks are from three different regions: (a) the Cooperative Bank of Chania in the region of Crete, (b) the Cooperative Bank of Epirus in the region of Epirus and (c) the Cooperative Bank of Evrou in the region of East Macedonia and Thrace. The examined cooperative banks met the capital requirements.

The analysis is based on the comparison of the structure of exposure values considering also differences and similarities between the two countries during the time period 2010-2016. Exposures are examined in borrower categories for which precise risk coefficients are considered.

The exposure values of Greek cooperative banks concentrate on medium and high risk weight, in contrast to Cypriot Central Cooperative Bank, which has a substantial part of exposure values in limited risk weight because of substantial exposure values in central government bonds.

After the introduction, section 2 discusses the consequences of capital adequacy on the evolution of Greek and Cypriot cooperative banking sectors. Section 3 offers a comparison of the exposures of cooperative banks in both countries before drawing up conclusions in Section 4.

\section{The consequences of capital requirements on the cooperative banking sectors}

\subsection{Crisis consequences on Greek cooperative banks}

The establishment of the Greek cooperative banks dates back in 1992 (Law 2076/1992) followed by the Act 2258/1993 of the Governor of the Bank of Greece. These two laws were supplemented by subsequent specifications of the laws and regulations of the Governor of the Bank of Greece, (Karafolas, 2016). According to Greek legislation, a credit cooperative can be established and function as a finan- 
cial institution; transacting mainly with its members, the state and the other financial institutions (Karafolas, 2016).

The development of the Greek credit cooperative system will be considered as to the change in total assets, number of branches and members. Based on Table 1, during the period 2000-2016, assets had grown by $358,2 \%$; the number of branches and members of cooperative banks rose by $143,5 \%$ and $87,7 \%$ respectively during the same time period. It is important to note the regional character of the Greek cooperative banks, since only two of them have branches outside their region: Pagritia Cooperative Bank and Cooperative Bank of Chania (Karafolas, 2016).

\section{Table 1. Consolidated assets, branches and members of the Greek cooperative banks, 2000-2016}

\begin{tabular}{|c|c|c|c|c|c|c|c|c|c|}
\hline & 2000 & 2005 & 2010 & 2011 & 2012 & 2013 & 2014 & 2015 & $2016 / 9$ \\
\hline Assets $^{1}$ & 548 & 2.042 & 4.447 & 3.610 & 3.610 & 3.216 & 3.261 & 2.539 & 2.511 \\
\hline Branches & 46 & 128 & 191 & 165 & 162 & 129 & 127 & 112 & 112 \\
\hline Members & 88.475 & 160.136 & 212.488 & 184.614 & 189.232 & 157.835 & 163.135 & 163.637 & 166.061 \\
\hline Number of banks 2 & 16 & 16 & 16 & 16 & 13 & 10 & 10 & 10 & 9 \\
\hline
\end{tabular}

SOURCE: Karafolas (2016) and Association of Cooperative Banks of Greece (2017).

1. In million Euros.

2. Number of banks: indicates only the banks with operations in the specific year.

It is noted that the growth that is observed until 2009, is counter weighted by the decline in years 2010 to 2016 (except for the number of members in certain years). Cooperative banks, just as all other Greek banks, suffered the economic consequences of the measures taken through the Memorandums of Understanding (MoU) agreed between the Greek State and its lenders (Bank of Greece, 2014). The measures taken had serious consequences on macroeconomic aggregates, bringing about a drop in the Gross Domestic Product, private consumption and investments; at the same time, it led to the growth of unemployment and non-performing loans (NPL), collected in Table 2. These developments had immediate consequences on the activities, on the profits and therefore on the capitalization needs of banks. 


\section{Table 2. Evolution of macroeconomic indicators of the Greek economy ${ }^{(1)}(\%)$}

\begin{tabular}{|c|c|c|c|c|c|c|c|c|}
\hline & 2009 & 2010 & 2011 & 2012 & 2013 & 2014 & 2015 & 2016 \\
\hline 1. Gross Domestic Product & $-2,3$ & $-4,2$ & $-9,2$ & $-7,3$ & $-3,2$ & 0,4 & $-0,3$ & 0,0 \\
\hline 2. Private consumption & $-1,8$ & $-4,1$ & $-9,9$ & $-7,9$ & $-2,7$ & 0,6 & $-0,3$ & 1,4 \\
\hline 3. Investments & $-11,4$ & $-17,4$ & $-20,7$ & $-23,4$ & $-8,3$ & $-4,4$ & $-0,2$ & 0,0 \\
\hline 4. Unemployment & 9,6 & 12,7 & 17,9 & 24,4 & 27,5 & 26,5 & 24,9 & 23,5 \\
\hline 5. Non-performing loans ratio & 7,7 & 10,4 & 16,0 & 24,5 & 31,9 & 39,4 & 43,2 & 44,8 \\
\hline
\end{tabular}

SOURCE: Author's calculations based on Bank of Greece (2015), Bank of Greece (2017a), Bank of Greece (2017b).

(1). 1, 2 and 3 describe the annual growth. 4 and 5 describe the ratio compared to the total at this year.

According to the MoU of 2012, between Greece and its lenders, non-significant banks had to be recapitalized from private sources by the end of April 2013 and/or merge with other banks by demonstrating a credible business plan and meeting recapitalization needs by April 2013. If private shareholders were unable to support these banks, the Bank of Greece would take those steps necessary to safeguard the financial stability and depositors' interests (Bank of Greece, 2014). In contrast to cooperative banks, the systemic, for the national economy, banks received an advance from the Hellenic Financial Stability Fund amounting to $€ 18$ billion towards their capital increase (Bank of Greece, 2012). Thus, systemic banks were recapitalized as a result of public support. This support was refused to nonsystemic banks (according to the ECB list) such as the cooperative banks in Greece (European Central Bank, 2017). Cooperative banks are considered to be non-systemic banks and as such they were left alone to achieve the necessary recapitalization through their members or through the private market. Seven Greek cooperative banks were not able to raise the necessary capital so as to meet the recapitalization requirements imposed by Basel II. As a result, the licenses of these seven cooperative banks and one more share bank hold by cooperative banks were revoked by the Bank of Greece. The Commission on Credit and Insurance Issues of the Bank of Greece examined the capital adequacy of cooperative banks, considering their own funds - capital requirements as described by Law number 3601 (Hellenic Republic, 2007), and the Bank of Greece Governor's Act 2630/29.10.2010 (Bank of Greece, 2010).

In 2012, the Bank of Greece revoked the licenses of three cooperative banks. The Commission on Credit and Insurance Issues (CCII) of the Bank of Greece considered that the Ahaiki Cooperative Bank was unable to fulfill capital obligations (of $€ 8$ million), due to high rates of non-performing loans (NPL), the lack of sufficient collateral and the lack of liquidity due to market conditions. For the same reasons, the CCII considered that the Cooperative Bank of Lamia was unable to reach its recapitalization target of $€ 1,1$ million, whereas the Lesvos-Limnos Cooperative Bank was unable to reach its recapitaliza- 
tion target of $€ 9,6$ million (Bank of Greece Commission on Credit and Insurance Issues, 2012a, 2012b and 2012c).

In December 2013, the Bank of Greece revoked the licenses of three more cooperative banks, the Cooperative Bank of Dodecanese, the Cooperative Bank of Evia and the Cooperative Bank of West Macedonia (Bank of Greece Commission on Credit and Insurance Issues, 2013, 2013a and 2013b). In the case of the Cooperative Bank of Dodecanese, the CCII estimated the amount of provision for doubtful debts had to increase to $€ 22,5$ million. In order to meet the capital shortfall caused by this increase in the doubtful debts, the bank had to increase its capital by $€ 10,6$ million. The bank through public contribution, accumulated $€ 5,3$ million, which was considered insufficient to restore its capital adequacy. Similarly, the CCII considered the Cooperative Bank of West Macedonia's own funds inadequate as a result of an increase of the provision for doubtful debts by $€ 12,98$ million. The bank accumulated $€ 5,2$ million through the private contribution and further $€ 5,2$ million through the issue of bonds to private investors, which however could not be considered as Core Equity Tier 1 capital. In the case of Cooperative Bank of Evia, the CCII estimated an amount of $€ 8,8$ million as necessary recapitalization amount. The bank managed to raise only an amount of $€ 324.000$ through private contribution, which was not considered sufficient to restore its capital adequacy.

In 2015, the license of two more banks associated with the cooperative banking sector was revoked. In December 2015, the license of the Cooperative Bank of Peloponnese was revoked by the Bank of Greece. The Resolution Measures Committee demanded that the Cooperative Bank of Peloponnese should raise additional $€ 14,3$ million by the $13^{\text {th }}$ of December in order to cover the capital requirements. Up to that date, the bank had accumulated only $€ 461.300$, which was considered as insufficient. Thus, the Cooperative Bank of Peloponnese was placed under special liquidation (Bank of Greece, 2015). In 2015, the CCII of the Bank of Greece put the Pan Hellenic Bank under special liquidation and appointed a special liquidator, according to article 145 of Law 4261/2014 (Bank of Greece 2015a). Pan Hellenic Bank was a share company created by Greek cooperative banks and received the support of the German cooperative bank, DZ Bank, which had, since $2005,10 \%$ of Pan Hellenic's share capital (Karafolas, 2016).

It is worth noting that the financial crisis of 2008 had its toll on both Greek cooperative banks and systemic banks alike (Table 2): high level of non-performing loans leading to capital inadequacy, difficulties in raising the needed additional share capital through the private market. However, the treatment of cooperative banks was different from systemic banks: cooperative banks were forced to raise the needed additional share capital on their own (through their members or private investors) whereas, four Greek systemic investor-owned banks were recapitalized through the Financial Stability Fund. However, this had led to the salvation of systemic investor-owned banks whereas, seven cooperative banks and a share bank hold by cooperative banks were lead to bankruptcy. 


\subsection{Crisis consequences to the Cypriot cooperative banks}

The first Cypriot cooperative bank was set up in 1909 with the founding of the "Rural Bank of Lefkoniko" (Cooperative Societies Supervision and Development Authority (CSSDA), 2014a), aiming at providing short and longer term financing for agricultural purposes (Argyridou-Dimitriou and Kanaris, 2012). Cooperative banks were created according to the Raiffeisen Credit System (Clerides, 1947), because their members were generally poor and they had smaller, more seasonal and thus more unpredictable income rendering the repayment of the loans on fixed loan instalments very difficult (Guinnane, 1994). To manage the unpredictability of borrowers' income, the Raiffeisen model relied on the strong feelings of solidarity among villagers to put pressure on borrowers to repay and reduce the information asymmetry (on villager's character, competence and on the way money was spend) (Guinnane, 1994).

In 1937, the Cooperative Central Bank was founded, aiming to create capital for the cooperative movement and to become self-financed, by borrowing from the wealthy and lending to the weaker cooperative institutions (CSSDA, 2014a). In addition, the Cypriot Cooperative Central Bank acted as the government representative for the financing of various developmental agricultural programmes (CSSDA, 2014a).

The first legal framework for cooperatives was put in place, in 1914, with the Cooperative Companies' Law of 1914 "Law 13 regarding the Cooperative Credit Companies" (CSSDA, 2014b). In 1985, the law was updated by Law 22/1985 and since then several times to improve its effectiveness and to update it (CSSDA, 2014b). Today, the cooperative credit institutions, for all matters that relate to their registration and operation as cooperative societies, are governed by the Cooperative Companies' Laws of 1985- 2016 (Cyprus Bar Association, 2018), the Cooperative Companies' Special Institutions of 1985- 2012 (CSSDA, 2018), and the instructions, decrees and circulars of the CSSDA Commissioner. Furthermore, since 2013 the supervision of credit unions passed from CSSDA to the Central Bank of Cyprus (based on the "Business of Credit Institutions Law of 1997 to (No.4) of 2013") (CSSDA, 2014b).

Following a request by Cyprus on 25 June 2012, the European Commission, the European Central Bank (ECB) and the International Monetary Fund (IMF) agreed an economic adjustment program with the Cypriot authorities on 2 April 2013. The program was agreed by euro area countries on 24 April 2013 and by the IMF Board on 15 May 2013. It covered the period 2013-16. The financial package covered up to $€ 10$ billion with the ESM providing up to $€ 9$ billion, and the IMF contributing around $€ 1$ billion (European Commission, 2017). The consequences of the adjustment program appear on Table 3 below. Based on this table, it is noted that during the years 2012-2014 there is an important drop of GDP as well as a growth of unemployment and non-performing loans. The economy started to recover from 2015 onwards (with the growth of GDP, and the fall of unemployment). On the contrary non-performing loans remained the main problem for the banks and the economy. 


\section{Table 3. Annual growth of macroeconomic indicators of the Cypriot economy ${ }^{(1)}(\%)$}

\begin{tabular}{|l|c|c|c|c|c|c|c|c|c|c|c|}
\hline \multicolumn{1}{|c|}{$\mathbf{2 0 0 8}$} & $\mathbf{2 0 0 9}$ & $\mathbf{2 0 1 0}$ & $\mathbf{2 0 1 1}$ & $\mathbf{2 0 1 2}$ & $\mathbf{2 0 1 3}$ & $\mathbf{2 0 1 4}$ & $\mathbf{2 0 1 5}$ & $\mathbf{2 0 1 6}$ & $\mathbf{2 0 1 7}$ \\
\hline 1.Gross Domestic Product & 3,9 & $-1,8$ & 1,3 & 0,3 & $-3,1$ & $-5,9$ & $-1,4$ & 2,0 & 3,4 & 3,9 \\
2.Unemployment (harmonized rate) & 3,7 & 6,5 & 5,9 & 9,6 & 13,7 & 16,3 & 16,6 & 13,1 & 12,9 & 10,5 \\
3.Non-performing loans to total loans ratio & & & 13,3 & 17,3 & 27,1 & 42,1 & 47,5 & 45,4 & 46,4 & 43,2 \\
& & & & & & & & & & (Sept) \\
\hline
\end{tabular}

SOURCE: Calculations by authors based on Central Bank of Cyprus (2018), for GDP and unemployment, and Central Bank of Cyprus (2018a), for NPL.

(1). 1 describes the annual growth. 2 and 3 describe the ratio compared to the total at this year.

The economic adjustment program with the Cypriot authorities imposed capital controls in March 2013. As a result of that a number of decrees concerning restrictions on banking transactions were issued including restrictions on cash withdrawals, in cashing cheques into cash and restrictions on money transfers to other credit institutions in Cyprus and abroad (which were lifted on 6 April 2015) (CCB, 2014). The financial crisis of March 2013 had also its toll on investors-owned banks, with the closure of the second largest bank and the transfer of its operations, assets and liabilities to the largest local bank and the subsequent issuance of $€ 1$ billion of new share capital to private investors (CCB, 2014). The crisis affected also the cooperative movement as on 5 September 2013 it was nationalised in order for the Cypriot government to be able to provide $€ 1,5$ billion for its recapitalisation (CCB, 2013). A very intensive merging of the cooperative banking sector took place in 2013 (CCB, 2013). The 97 cooperative credit institutions that existed in 2012 were merged to just 19 in 2013, as it appears on Table 4. Moreover, on 1 July 2017 the 18 remaining cooperative credit institutions were merged into the Cooperative Central Bank (CCB) and the number of branches were reduced to 160 (from 246 in 2016) (Stockwatch, 2017). 


\section{Table 4. Consolidated assets, branches and members of the Cypriot cooperative credit institutions, 2000-2016}

\begin{tabular}{|c|c|c|c|c|c|c|c|c|c|}
\hline & $2000^{1}$ & $2005^{2}$ & $2010^{2}$ & $2011^{2}$ & $2012^{2}$ & $2013^{2}$ & $2014^{2}$ & $2015^{2}$ & $2016^{2}$ \\
\hline Assets $^{3}$ & 5.465 & 8.448 & 19.936 & 20.714 & 21.169 & 15.209 & 13.937 & 14.307 & 14.101 \\
\hline No. of branches & & 476 & 426 & 430 & 420 & 349 & 292 & 251 & 246 \\
\hline No. of Members & 361.066 & 536.000 & 633.620 & 626.263 & 621.967 & 554.363 & 550.125 & 600.000 & 201.000 \\
\hline No. of banks & 360 & 347 & 111 & 102 & 97 & 19 & 19 & 19 & 18 \\
\hline
\end{tabular}

1. SOURCE: CSSDA (2002, pp. 8, 18, 22), Excludes Coop Central Bank.

2. SOURCE: EACB (2018).

3. In million euros.

The merger of the 18 cooperative credit institutions into the CCB enabled the issue of new shares to the Cyprus government in exchange for 1,5 billion euros (which was obtained in the form of bonds from the European Stability Mechanism) (CCB, 2013). Thus, the government became the major shareholder with $99 \%$ of the shares and the votes and the existing shareholders were left with only $1 \%$ of the votes and shares in Cooperative Central Bank (CCB, 2013). To this effect, the Cooperative Holding Company of the Cooperative Central Bank was set up and all existing shareholders were transferred to it, based on each one's shareholding in the Cooperative Central Bank (CCB, 2013). Moreover, the shareholding of Cooperative Central Bank in each cooperative credit institution amounts to $99 \%$ regardless of the shareholding of the Cyprus State in Cooperative Central Bank and remains unchanged throughout the period during which the Cyprus State remains a shareholder in Cooperative Central Bank (CCB, 2013). The remaining 1\% shareholding and voting rights in each credit union belong to the existing shareholders (CCB, 2013). For this purpose, a holding company in each credit union was set up, in accordance to the Cooperative Societies Act, to which the existing shareholders of the credit union are transferred, and the shares of the holding company are distributed to the existing shareholders based on each one's shares and voting rights in the credit union (CCB, 2013). The Cypriot government has declared that due to its agreement within the adjustment program, it will have to sell/dispose at least $75 \%$ of its shareholding in Cooperative Central Bank in 3 junks (until 30 September 2018, 30 June 2019 and 30 June 2020) of 25\% each either through the Cyprus Stock Exchange or through private placement (Philenews, 2016). To this effect, Cooperative Central Bank has started the procedure to obtain a listing on the Cypriot Stock Exchange by June 2017 (Philenews, 2016). On 18 April 2017, it was announced that the Cooperative Central Bank agreed with Altamira for the comanagement of the Cooperative Central Bank's $€ 7,2$ billion non-performing loans (Philenews, 2017). On 3 April 2018, following the fleet of deposits from the Cooperative Central Bank as a consequence of rumours about its future, the government deposited another $€ 2,5$ billion, receiving as securities the non-performing loans and property amounting to around $€ 7,6$ billion to $€ 10$ billion (Philenews, 2018b). In the meantime, negotiations have started with the second largest investor-owned bank in Cyprus 
and a US-based Capital Management company for the purchase of either the whole or just the "good" Cooperative Central Bank (BusinessMail, 2018). This has resulted in the absorption of 1.100 employees, all branches, almost all performing loans, bonds, deposits and other assets of the Cooperative Central Bank to the second largest investor-owned bank for an amount of $€ 74,2$ million with the nonperforming loans and property to remain with the Cooperative Central Bank (Stockwatch, 2018), leading to a negative goodwill of $€ 300$ million (Stockwatch, 2018a). To incentivise the deal, the Cypriot state guaranteed an amount between $€ 500$ million- $€ 800$ million to the investor-owned bank (Philenews, 2018c).

\section{Exposures for cooperative banks}

Exposures can be examined from two angles: on the basis of borrower categories and the risk weighting that indicated the risk of the exposure. Procedures for the regulation appear in the mandatory statutory framework of Law 3016/2002, Law 4261/2014 (Hellenic Republic, 2014), Bank of Greece Governor's Directive No 2577/9.3.2006 (Bank of Greece, 2006) and Capital Market Commission Resolution No 5/204/14.11.2000 (see Piraeus Bank, 2015).

Borrowers' exposures are presented in 14 categories, covering the public and private sectors as well as financial institutions. In addition to these, two other categories exist which cover the particularly high risk exposures and exposures in default. The 14 categories are as follows (see also Karafolas, 2017): (a) Central governments and central banks, (b) Regional governments and local authorities, (c) Public sector entities, (d) Financial institutions, (e) Parent companies and affiliates, (f) Multilateral development banks, (g) International organizations, (h) Corporate customers, (i) Retail customers, (j) Security by mortgages on immovable property, (k) Exposures in default, (I) Items associated with particularly high risk, $(m)$ Equity exposures, (n) Other items. A risk weighting is applied to every exposure, determined by its associated risk. The weighting risks are 0\%,20\%,35\%,50\%,75\%, 100\%, 150\%, >150\% respectively. Several conditions are considered to determine the risk of each exposure. The higher secured an exposure is considered, the lower the risk weighting applied. Some exposures are considered high risk and therefore take a high risk weighting, for example, exposures to corporate customers and exposures in default. Exposures to central governments are usually considered as fully guaranteed and therefore take a very low or even zero risk weighting. An intermediate case relates to exposures secured by a mortgage, commercial or real estate; usually having a risk weighting of $50 \%$. Different risk weightings may be applied to the same class of borrower since in the same category, some exposures may be covered by a guarantee and others are not (see on this point European Parliament and European Council, 2013). 


\subsection{Methodology and data}

The purpose of this article is to examine the comportment of Greek cooperative banks compared to the Cypriot cooperative institutions/ Cyprus Cooperative Central Bank regarding the exposures on the basis of borrower categories.

- Have Greek and Cypriot cooperative banks followed a conservative or a risky policy during the crisis period?

- In this period, have these policies changed or not?

One way of answering these questions is by examining the asset categories, as they determine the risk weighted exposures.

In the Greek case we estimated the average exposures by borrower category of three Greek cooperative banks (Cooperative bank of Chania, Cooperative Bank of Epirus, Cooperative Bank of Evrou) for which data was available, each of which operates in a different region. By the end of 2016, the first one had a banking network of 23 branches, 20 in Crete and 3 in Athens and total assets of $€ 443$ million; the second one a network of 9 branches and total assets of €203 million; and the last one had a network of 5 branches and total assets of $€ 52$ million (Association of Cooperative Banks of Greece, 2017). In the Cypriot case, we considered the Cooperative Central Bank. Data is provided in annual bank reports on capital adequacy and risk management regulatory disclosures according to Pillar III. The time period examined is from 2010 to 2016. This period is the crucial period of the Greek crisis after the memorandum of understanding that Greece signed with its lenders (Bank of Greece, 2014). For Cyprus the most crucial period is 2012 to 2016 since on 2012 Cyprus asked the financial help from $\mathrm{EU}$ and the IMF. One must note that Cyprus was the country most affected from the Greek crisis because of the exposure of Cypriot banks in the Greek market and also the operation of Greek banks in the Cyprus financial industry.

For both Greek and Cypriot cases, the following categories are examined: (a) Central governments and central banks, (b) Regional governments and local authorities, (c) Financial institutions, (d) Corporate customers, (e) Retail customers, (f) Secured mortgages on immovable property, (g) Exposures in default, (h) Exposures to high risk, (i) Equity exposures, (j) Other items. Please note that in the Cypriot case, "Exposures to high risk" and "Equity exposures" are included to the category of "Other Items".

\subsection{Results for Greek cooperative banks}

The results are considered on a consolidated basis. Exposures are concentrated to high weighting risks mainly of $75 \%, 100 \%$ and $150 \%$. Apart from Exposures in default with an average of $24,1 \%$, Exposures on secured mortgages represent the second biggest category of exposures $(20,9 \%$ on aver- 
age for the period), which take a medium weighting risk of $50 \%$ in most cases, according to Table 5 . The third and fourth biggest exposure is Exposures to retail customers $(16,8 \%)$ and Exposures to corporate customers $(15,2 \%)$, which take a high weighting risk, usually $75 \%$ and $100 \%$, respectively. It is worth noting that during the examined period, Exposures on secured mortgages seem to continuously grow in contrary to the drop of the part of Exposures to retail and corporate customers, as shown in Table 5. Contrary to these categories, Exposures to central government and central banks concentrate only $2,6 \%$ of total exposures (these exposures are considered secure having usually a risk coefficient of $0 \%$ ).

\section{Table 5. Ratio of asset categories to total exposure: average of consolidated exposures for the three Greek cooperative banks (\%)}

\begin{tabular}{|c|c|c|c|c|c|c|c|c|}
\hline Asset exposure category & 2010 & 2011 & 2012 & 2013 & 2014 & 2015 & 2016 & $\begin{array}{l}\text { Average } \\
\text { for the } \\
\text { period }\end{array}$ \\
\hline $\begin{array}{l}\text { Central Governments and } \\
\text { central banks }\end{array}$ & $0 \%$ & $2 \%$ & $2 \%$ & $4 \%$ & $5 \%$ & $1 \%$ & $4 \%$ & $2,6 \%$ \\
\hline $\begin{array}{l}\text { Regional governments and } \\
\text { local authorities }\end{array}$ & $0 \%$ & $1 \%$ & $1 \%$ & $1 \%$ & $1 \%$ & $1 \%$ & $1 \%$ & $0,8 \%$ \\
\hline Financial institutions & $2 \%$ & $5 \%$ & $8 \%$ & $5 \%$ & $5 \%$ & $2 \%$ & $1 \%$ & $4,4 \%$ \\
\hline $\begin{array}{l}\text { Secured mortgages on } \\
\text { immovable property }\end{array}$ & $16 \%$ & $19 \%$ & $19 \%$ & $19 \%$ & $18 \%$ & $26 \%$ & $26 \%$ & $20,9 \%$ \\
\hline Retail customers & $24 \%$ & $20 \%$ & $19 \%$ & $15 \%$ & $16 \%$ & $15 \%$ & $14 \%$ & $16,8 \%$ \\
\hline Corporate customers & $27 \%$ & $22 \%$ & $19 \%$ & $16 \%$ & $11 \%$ & $9 \%$ & $9 \%$ & $15,2 \%$ \\
\hline Exposures in default & $17 \%$ & $19 \%$ & $18 \%$ & $20 \%$ & $31 \%$ & $32 \%$ & $30 \%$ & $24,1 \%$ \\
\hline Equity exposures & $8 \%$ & $4 \%$ & $4 \%$ & $4 \%$ & $5 \%$ & $5 \%$ & $5 \%$ & $4,7 \%$ \\
\hline Exposures to high risk & $4 \%$ & $5 \%$ & $7 \%$ & $13 \%$ & $4 \%$ & $1 \%$ & $3 \%$ & $5,3 \%$ \\
\hline Other items & $3 \%$ & $4 \%$ & $4 \%$ & $5 \%$ & $5 \%$ & $8 \%$ & $9 \%$ & $5,3 \%$ \\
\hline Total & $100 \%$ & $100 \%$ & $100 \%$ & $100 \%$ & $100 \%$ & $100 \%$ & $100 \%$ & $100,0 \%$ \\
\hline
\end{tabular}

SOURCE: Author's calculations based on Cooperative Bank of Epirus (2018), Cooperative Bank of Evrou (2018), and Cooperative Bank of Chania (2018).

Difficulties arising from non-performing loans appear in Exposures in default. Their share in total exposures grew up continually this period from $17 \%$ in 2010 to $30 \%$ in 2016, according to Table 5 . This increase seems to be the result of a considerable portion of loans that were provided to businesses and in retail banking. All of these placements carry a significant risk, especially during a crisis period, 
and in this particular case, it led to the increase of the weighted asset and hence the difficulties in achieving the $8 \%$ capital ratio.

As presented on Table 2, non-performing loans (NPL) grew rapidly during the period under examination. Their ratio to the total amount of loans was 7,7\% in $2009,24,5 \%$ in 2012 and rose to $44,8 \%$ in 2016. As Table 6 shows, NPLs granted to small businesses and professionals are the most significant as they represent $68,3 \%$ of this category; followed by NPL on Small and Medium Enterprises (SMEs) being 60,7\%, and consumer loans with a 54\% share of the NPLs. This seems to be in line with cooperative banks' specialization in meeting the needs of SMEs and small professionals; consequently they were more exposed to bad loans during the crisis period as can be seen from the preponderance of ESxposures in default. In contrast, the cooperative banks' policy towards public bonds was very limited compared to systemic banks.

\section{Table 6. Non-performing exposures of the Greek banks}

\begin{tabular}{|c|c|c|}
\hline & 2015 & 2016 \\
\hline Consumer loans & $54,70 \%$ & $54,0 \%$ \\
\hline Residential loans & $41,0 \%$ & $41,5 \%$ \\
\hline Business loans & $43,8 \%$ & $44,6 \%$ \\
\hline 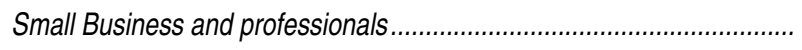 & $63,0 \%$ & $68,3 \%$ \\
\hline SMES & $54,0 \%$ & $60,7 \%$ \\
\hline
\end{tabular}

SOURCE: Bank of Greece (2017 and 2017a).

\subsection{Results for Cypriot Central Cooperative Bank}

The above picture is similar in the case of Central Cooperative Bank (CCB), as shown in Table 7. A notable part of exposures relate to categories considered as of relatively high risk (risk coefficient $75 \%$ ), and medium risk (risk coefficient $50 \%$ ), but also to categories of zero risk i.e., as secure (risk of $0 \%$ ). Considering the average figures for the period 2010-2016, CCB concentrates the bigger part of Exposures to retail customers (23\%), followed by Exposures to central government or central banks (22\%). This part of exposures differentiates the CCB from Greek cooperative banks that have not bought Greek bonds. Exposures on secured mortgages represent $16 \%$ of total exposures that approaches the Greek case (20,9\%). In the case of Exposures to corporate customers, CCB has only a 2\% exposure as opposed to the Greek cooperatives that have a 15,2\% exposure. Exposures in default are very similar for both Cypriot and Greek cases with on average $25 \%$ of total exposures in the Cypriot case and representing almost $24 \%$ on average in the Greek case. Also, it is worth mentioning that these expo- 
sures represent a growing percent of total exposures as it appears on Table 7. Exposures in default are related to the non-performing loans that have a huge growth on 2012 and 2013, according to Table 3. Since 2013, NPL are more than $40 \%$ of total loans. This increase of Exposures in default seems to be a direct consequence of the economic recession and the accumulated problems and it is similar to the findings of Duchin et all, 2014, that concluded that, after receiving government support, bailout banks granted riskier loans. The increase of Exposures in default seems to relate to the findings of Hryckiewicz (2014), who concluded that the Government's intervention to the banking crisis had a negative impact on banking stability, increasing its risk. From the above figures we can also argue that during the examined period CCB followed a more conservative policy that is reflected by the growth of Exposures to central government and central bank especially since 2015. On the contrary, exposures related to retail banking were reduced, in total exposures, from $33 \%$ in 2010 to just $14 \%$ in 2016, as shown in Table 7.

Systemic banking crises have placed enormous pressure on national governments to intervene. The empirical literature, however, is inconclusive on what an optimal bailout program should look like in order to mitigate the negative consequences of government interventions on the banking sector. Based on our findings, it seems that general government interventions have a negative impact on the stability of the banking sector, significantly increasing its risk.

\section{Table 7. Ratio of asset categories to total exposure (\%)}

\begin{tabular}{|l|r|r|r|r|r|r|r|r|}
\hline Asset exposure category & $\mathbf{2 0 1 0}$ & $\mathbf{2 0 1 1}$ & $\mathbf{2 0 1 2}$ & $\mathbf{2 0 1 3}$ & $\mathbf{2 0 1 4}$ & $\mathbf{2 0 1 5}$ & $\mathbf{2 0 1 6}$ & $\begin{array}{c}\text { Average } \\
\text { for the } \\
\text { period }\end{array}$ \\
\hline $\begin{array}{l}\text { Central Governments or } \\
\text { central banks, }\end{array}$ & $18 \%$ & $20 \%$ & $21 \%$ & $19 \%$ & $12 \%$ & $29 \%$ & $32 \%$ & $22 \%$ \\
$\begin{array}{l}\text { Regional governments or } \\
\text { local authorities }\end{array}$ & $3 \%$ & $3 \%$ & $2 \%$ & $3 \%$ & $3 \%$ & $3 \%$ & $2 \%$ & $3 \%$ \\
Financial Institutions & $2 \%$ & $2 \%$ & $1 \%$ & $1 \%$ & $1 \%$ & $1 \%$ & $1 \%$ & $1 \%$ \\
$\begin{array}{l}\text { Secured mortgages on } \\
\text { immovable property }\end{array}$ & $17 \%$ & $18 \%$ & $18 \%$ & $18 \%$ & $13 \%$ & $15 \%$ & $16 \%$ & $16 \%$ \\
Retail customers & $33 \%$ & $28 \%$ & $25 \%$ & $25 \%$ & $22 \%$ & $16 \%$ & $14 \%$ & $23 \%$ \\
Corporate customer & $2 \%$ & $4 \%$ & $4 \%$ & $3 \%$ & $2 \%$ & $1 \%$ & $1 \%$ & $2 \%$ \\
Exposures in Default & $20 \%$ & $21 \%$ & $23 \%$ & $25 \%$ & $31 \%$ & $29 \%$ & $28 \%$ & $25 \%$ \\
Other items & $5 \%$ & $5 \%$ & $5 \%$ & $6 \%$ & $6 \%$ & $5 \%$ & $7 \%$ & $7 \%$ \\
\hline Total & $100 \%$ & $100 \%$ & $100 \%$ & $100 \%$ & $100 \%$ & $100 \%$ & $100 \%$ & $100 \%$ \\
\hline
\end{tabular}

SOURCE: CCB (2018). 
Based on our findings both, Greek and Cypriot cooperative banks follow a more conservative policy, preferring secure exposures over less secure lending. This evolution is in line with findings in other cases, e.g., Carvalho et all. (2015) who found that during crisis period banks tend to reduce their exposure to corporate clients, especially to those in a weak financial position. Also, Gauvin (2014) concluded that during an upward phase of the economy, banks favor riskier assets while during a downward phase they prefer safer assets. In the case of CCB the purchase of sovereign holdings is in line with findings of Altavilla et al. (2016), who concluded that bailed out and poorly capitalized banks responded to the public requests by purchasing domestic public debt more than other banks.

\section{Conclusions}

The global financial crisis of 2008 had economic and social consequences to many countries. Greece and Cyprus were not immune from this crisis and they were forced to apply for financial assistance from the European Union and the International Monetary Fund. The already difficult economic environment has been worsened even further by the consequences of the economic adjustment programs, having a real toll on the real economy and hence on the servicing of bank loans. In turn the nonperforming loans and asset exposures have created huge needs for additional share capital, in a time when private funds were difficult to be attracted. The resulted capital inadequacy contributed towards the failure of banks that did not succeed to accomplish the capital requirements set by Basel II requirements.

National governments did not treat systemic and non-systemic banks the same as those banks that were considered significant for the economy received capital aid from the state. However, non-significant banks did not receive any state aid. In the Greek case, cooperative banks could not receive the financial aid in order to achieve their recapitalization as required by Basel II and as a consequence seven cooperative banks were declared as bankrupt. In the case of Cyprus, a huge change on the structure of the cooperative credit system took place with the merge of 360 credit cooperatives in 2000 into 18 cooperatives in 2013 and then into a single in, the Cooperative Central Bank in 2017. The Cooperative Central Bank became a systemic bank and hence eligible to obtain financial assistance from the European Stability Mechanism for its recapitalization.

The examination of consolidated exposures of three cooperative banks in Greece and the Cypriot Central Cooperative Bank during the crisis period showed that the exposures of cooperative banks have a high weighted risk because traditionally, cooperative banks have concentrated mainly in retail banking and small companies and professionals (especially in the Greek case). Thus, cooperative banks had to face bigger problems than other similar banks, due to the higher rate of non-performing loans in the type of loans in which cooperatives specialize. The consequences from the non-perform- 
ing loans increased the exposures in default that grew up dramatically in the last years of the period under examination. Cooperative banks had to follow a more conservative policy that appears on the structure of the asset exposures with the growth of the part of banks' exposures to central government and central banks (with the lower risk weighted) and those secured with mortgage in the Greek case.

\section{References}

ALTAVILLA, C., PAGANO, M. \& SIMONELLI, S. (2016): "Bank Exposures and Sovereign Stress Transmission", Working Paper Series. ESRB, 11, May, DOI.ORG/10.2139/ssrn.2848937.

ARGYRIDOY DIMITRIOU, C. \& KANARIS, E. (2012): "The financial system of Cyprus". In: Orphanides, A. \& Syrichas, G. (Ed.), The Cyprus economy. Historical review, prospects, challenges, Central Bank of Cyprus, 280-284.

http://www.centralbank.gov.cy/media/pdf/CBC_book_EN.pdf (Accessed in July 2018).

ASSOCIATION OF GREEK COOPERATIVE BANKS (2017): "Financial data".

http://www.este.gr/index.asp (Accessed in June 2018).

BANK OF GREECE (2006): "Bank of Greece Governor's Directive (BGGD) No 2577/9.3.2006".

https://www.bankofgreece.gr/BogDocumentEn/GA.BG_2577-

9.03.2006_Annex_1_Outsourcing_activities_to_third_parties.pdf

BANK OF GREECE (2010): "Bank of Greece Governor's Act 2630/29.10.2010 on Definition of own capital of credit institutions with headquarter in Greece".

http://www.bankofgreece.gr/Pages/el/Bank/LegalF/Acts.aspx

BANK OF GREECE (2012): "Report on recapitalization and restructuring of the Greek banking sector". http://www.bankofgreece.gr/Pages/en/Bank/News/PressReleases/Displtem.aspx?Filter_by=DT\&ltem_ID $=4132 \&$ List_ID=1af869f3-57fb-4de6-b9ae-bdfd83c66c95.

BANK OF GREECE COMMISSION ON CREDIT AND INSURANCE ISSUES (2012a): "Decision of the Commission on Credit and Insurance Issues of the Bank of Greece 34/1/18.3.2012 on the recall of license for the cooperative Bank of Lesvos-Limnos".

http://www.bankofgreece.gr/Pages/el/Bank/LegalF/Decisionsepath.aspx

BANK OF GREECE COMMISSION ON CREDIT AND INSURANCE ISSUES (2012b): "Decision of the Commission on Credit and Insurance Issues of the Bank of Greece 34/2/18.3.2012 on the recall of license for Ahaiki Cooperative Bank".

http://www.bankofgreece.gr/Pages/el/Bank/LegalF/Decisionsepath.aspx 
BANK OF GREECE COMMISSION ON CREDIT AND INSURANCE ISSUES (2012C): "Decision of the Commission on Credit and Insurance Issues of the Bank of Greece 34/3/18.3.2012 on the recall of license for Cooperative Bank of Lamia".

http://www.bankofgreece.gr/Pages/el/Bank/LegalF/Decisionsepath.aspx

BANK OF GREECE COMMISSION ON CREDIT AND INSURANCE ISSUES (2013): "Decision of the Commission on Credit and Insurance Issues of the Bank of Greece 97/1/08.12.2013 on the recall of license for the cooperative Bank of West Macedonia".

http://www.bankofgreece.gr/Pages/el/Bank/LegalF/Decisionsepath.aspx

BANK OF GREECE COMMISSION ON CREDIT AND INSURANCE ISSUES (2013a): "Decision of the Commission on Credit and Insurance Issues of the Bank of Greece 97/2/08.12.2013 on the recall of license for Cooperative Bank of Evia".

http://www.bankofgreece.gr/Pages/el/Bank/LegalF/Decisionsepath.aspx

BANK OF GREECE COMMISSION ON CREDIT AND INSURANCE ISSUES (2013b): "Decision of the Commission on Credit and Insurance Issues of the Bank of Greece 97/3/08.12.2013 on the recall of license for Cooperative Bank of Dodecanese".

http://www.bankofgreece.gr/Pages/el/Bank/LegalF/Decisionsepath.aspx

BANK OF GREECE (2014): "The chronicle of the great crisis", The Bank of Greece. https://www.bankofgreece.gr/BogEkdoseis/The\%20Chronicle\%200f\%20The\%20Great\%20Crisis.pdf.

BANK OF GREECE (2015): "Resolution Measures Committee, Decision 28/18-12-2015 Application of the transfer order of the article 38 of article 2 of Law 4335/2015 to the credit institution under the name Cooperative Bank of Peloponnese".

http://www.bankofgreece.gr/Pages/el/Bank/LegalF/decisionseme.aspx

BANK OF GREECE COMMISSION ON CREDIT AND INSURANCE ISSUES (2015a): "Decision 136/17.4.2015 on Position of the credit institution "Pan Hellenic Bank SA" under a special liquidation and appointment of a special liquidator Greece".

http://www.bankofgreece.gr/Pages/el/Bank/LegalF/Decisionsepath.aspx

BANK OF GREECE (2017): Overview of the Greek Financial system, Bank of Greece, Athens.

BANK OF GREECE (2017): Monetary policy for 2016-2017, Bank of Greece, Athens.

BANK OF GREECE (2017): Bulletin of Conjunctural Indicators, no 166, no 171.

BASEL COMMITTEE ON BANKING SUPERVISION (2006): "International Convergence of Capital Measurement and Capital Standards", Bank for International Settlements, Basel. https://www.bis.org/publ/bcbs128.htm

BUSINESSMAIL (2018): "Coop receives two binding offers from investors (Update-2)". http://cyprusbusinessmail.com/?p=63665 (Accessed in May 2018). 
CARVALHO, D., FERREIRA, M. \& MATOS, P. (2015): "Lending Relationships and the Effect of Bank Distress: Evidence from the 2007-2009 Financial Crisis", Journal of Financial and Quantitative Analysis, 50, 1165-1197, DOI.ORG/10.1017/S0022109015000551.

CENTRAL BANK OF CYPRUS (2018): Statistics2017. https://www.centralbank.cy/en/statistics/economic-indicators (Accessed in March 2018).

CENTRAL BANK OF CYPRUS (2018): Aggregate Cyprus banking sector. https://www.centralbank.cy/images/media/redirectfile/2018_01_09 Aggregate Cyprus banking sector data on NPFs_30.9.2017.xls, (Accessed in May 2018).

CLERIDES, N. (1947): "A historical note" in "Cooperation in Cyprus (each for all and all for each)", Registrar of Cooperative Societies, no. 7.

COOPERATIVE BANK OF CHANIA (2018): Disclosure Pillar III for years 2016 to 2010. https://www.chaniabank.gr/el/the-group/bank/corporate-governance/internal-control-system/riskmanagement/pillar-iii.aspx (Accessed in May 2018) (in Greek).

COOPERATIVE BANK OF EPIRUS (2018): Disclosure Pillar III for years 2016 to 2011.

http://www.epirusbank.com/trapeza/pliroforisi-ependyton/epoptikes-arhes/article/epoptikes-arhes (Accessed in May 2018) (in Greek).

COOPERATIVE BANK OF EVROU (2018): Disclosure Pillar III for years 2016 to 2011. http://evrosbank.gr/financial.html (Accessed in May 2018) (in Greek).

COOPERATIVE CENTRAL BANK (CCB) (2013): Report and Consolidated Financial Statements for the year ended 31 December 2013.

http://www.ccb.coop.com.cy/userfiles/f8ce1af3-1709-4976-a7851a5a8d552da1/COOPconsolFS2013.pdf (Accessed in March 2018).

COOPERATIVE CENTRAL BANK (CCB) (2014): Report and Consolidated Financial Statements for the year ended 31 December 2014.

http://www.ccb.coop.com.cy/userfiles/f8ce1af3-1709-4976-a7851a5a8d552da1/oikonomikeskatastaseis2014.pdf (Accessed in March 2018).

COOPERATIVE CENTRAL BANK (CCB) (2018): Pillar III information disclosures. http://www.ccb.coop.com.cy/AboutCCB/pylwnas3/ (Accessed in March 2018).

COOPERATIVE SOCIETIES SUPERVISION AND DEVELOPMENT AYTHORITY (CSSDA) (2002): Annual Report for 2000-2002.

http://www.cssda.gov.cy/cssda/cssda02.nst/All/80F27A06AFE9E036C2257C3D00289409/ \$file/\%CE\%95\%CF\%84\%CE\%AE\%CF\%83\%CE\%B9\%CE\%B1\%20\%CE\%88\%CE\%BA\%CE\%B 8\%CE\%B5\%CF\%83\%CE\%B7\%202000-2002.pdf (Accessed in July 2018). 
COOPERATIVE SOCIETIES SUPERVISION AND DEVELOPMENT AUTHORITY (CSSDA) (2014a): CSSDA: Presentation.

http://www.cssda.gov.cy/cssda/cssda02.nsf/page11_gr/page11_gr?OpenDocument (Accessed in July 2018).

COOPERATIVE SOCIETIES SUPERVISION AND DEVELOPMENT AYTHORITY (CSSDA) (2014b): CSSDA: General (Accessed in July 2018).

COOPERATIVE SOCIETIES SUPERVISION AND DEVELOPMENT AUTHORITY (CSDA) (2018): Cooperative Companies' Special Institutions of 1985- 2012. http://www.cssda.gov.cy (Accessed in May 2018).

CYPRUS BANK ASSOCIATION (2018): Cooperative Companies' Laws of 1985-2016. http://www.cylaw.org/nomoi/enop/non-ind/1985_1_22/full.html (Accessed in May 2018).

DUCHIN, R. \& SOSYURA, D. (2014): "Safer ratios, riskier portfolios: Banks' response to government aid", Journal of Financial Economics, 113 (1), 1-28, DOI.ORG/10.1016/j.jfineco.2014.03.005.

EUROPEAN ASSOCIATION OF CO-OPERATIVE BANKS (EACB) (2018): Key Statistics - Financial indicators, http://www.eacb.coop/en/cooperative-banks/key-figures.html (Accessed in May 2018).

EUROPEAN CENTRAL BANK (2017): Banking supervision, List of supervised banks as 1 July 2017, ECB. https://www.bankingsupervision.europa.eu/banking/list/who/html/index.en.html

EUROPEAN CENTRAL BANK (2017): Report on Financial structures, October, Table 6. https://www.ecb.europa.eu/pub/pdf/other/reportonfinancialstructures201710.en.pdf

EUROPEAN COMMISSION (2016): Financial Assistance to Cyprus. https://ec.europa.eu/info/business-economy-euro/economic-and-fiscal-policy-coordination/eu-financial-assistance/which-eucountries-have-received-assistance/financial-assistance-cyprus_en\#economicadjustmentprogrammeforc yprus (Accessed in November 2017).

EUROPEAN PARLIAMENT AN EUROPEAN COUNCIL (2013): Regulation (EU) No. 575/2013 on Prudential Requirements for Credit Institutions and Investment Firms and Amending Regulation (EU) No. 648/2012. http://eur-lex.europa.eu/legal-content/en/TXT/?uri=celex\%3A32013R0575

GAUVIN, M-S. (2014): "Bank Characteristics and Procyclicality: A Theoretical Approach", Journal of Financial Risk Management, 3, 57-66, DOI.ORG/10.4236/jfrm.2014.33007.

GUINNANE, T. (1994): "A failed transplant: Raiffeisen's Credit Cooperatives in Ireland, 1894-1914", Explorations in Economic history, 31, 38-61. DOI.ORG/10.1006/EXEH.1994.1002 (Accessed on 15 July 2018).

HELLENIC REPUBLIC (2007): "Taking up and pursuit of the business of credit institutions, capital adequacy of credit institutions and investment firms, and other provisions", Gazette of the Hellenic Republic, issue 178/ 1.8.2007. http://www.bankofgreece.gr/Pages/en/Bank/LegalF/laws.aspx. 
HELLENIC REPUBLIC (2014): "Law 4261/2014, Access to the activityof credit institutions and prudential supervisionofcredit institutions and enterprises (transposition of Directive 2013/36/EU), abolitionof the I.3601/2007and other provisions", Gazette of the Hellenic Republic, issue 107/ 5.5.2014. https://www.bankofgreece.gr/BogDocumentEn/LAW_4261_OF_2014.pdf.

HRYCKIEWICZ, A. (2014): "What do we know about the impact of government interventions in the banking sector? An assessment of various bailout programs on bank behavior", Journal of Banking and Finance, 46, 246-265, DOI.ORG/10.1016/j.jbankfin.2014.05.009.

KARAFOLAS, S. (2016): "The credit cooperative system in Greece”. In: Karafolas, S. (Ed.), Credit cooperative institutions in European Countries, Springer, Kozani.

KARAFOLAS, S. (2017): "Credit Risk Management: An Examination on the Basis of Exposures with Risk Weighting in Greek Banks", Journal of Financial Risk Management, 6, 101-118, DOI: 10.4236/JFRM.2017.62009.

PHILENEWS (2016): "The process for the flotation of Cooperative Central Bank on the Cyprus Stock Exchange has started". http://www.philenews.com/el-gr/oikonomia-kypros/146/310045/prochorai-eisagogi-tou-synergatismou-sto-chrimatistirio (Accessed in April 2016).

PHILENWES (2017): "Cypriot-Spanish platform for NPL of $€ 7.2$ billion of Cooperative Central Bank". http://www.philenews.com/oikonomia/kypros/article/416058/kypro-ispaniki-platforma-skt-ga-npls7-2-dis (Accessed in July 2018).

PHILENEWS (2018a): "Cooperatives enter a new era". http://www.philenews.com/oikonomia/kypros/article/489855/se-nea-epochi-perna-o-synergtismos (Accessed in July 2018).

PHILENEWS (2018b): "Government gave $€ 2,5 b i l l i o n$ to Cooperative Central Bank with triple target". http://www.philenews.com/oikonomia/kypros/article/508721/-2-5-dis-kybernisis-se-skt-me-triplostocho (Accessed in July 2018).

PHILENEWS (2018c): "Closes the deal with Cooperative Central Bank, exit route for 800 employees". http://www.philenews.com/oikonomia/kypros/article/538356/kleinei-to-deal-me-skt-stin-portaexodoy-800-ypalliloi (Accessed in June 2018).

PIRAEUS BANK (2015): Capital Adequacy and Risk Management Regulatory Disclosures on a Consolidated Basis for the Year 2014 (Pillar III), Piraeus Bank, Athens.

STOCKWATCH (2018): "Evaluation of the transfer of Cooperative Central Bank's operations to Hellenic Bank". https://www.stockwatch.com.cy/el/article/trapezes/apotimisi-tis-metaforas-ergasion-skt-se-elliniki (Accessed on December 2018).

STOCKWATCH (2018): "Hellenic Bank: mammoth profits after the transfer of Cooperative Central Bank". https://www.stockwatch.com.cy/el/article/trapezes/elliniki-kerdi-mamoyth-meta-ton-synergatismo (Accessed in December 2018). 
